\title{
Reciprocity vs. commitment in bank marketing strategies
}

\author{
Sergio Da Silva ${ }^{\text {abc }}$, Raul Matsushita ${ }^{\text {def }}$, Barbara Espirito Santo ${ }^{\mathrm{a}}$, Felipe Sigrist ${ }^{\mathrm{b}}$ \\ ${ }^{a}$ Department of Economics, Federal University of Santa Catarina, 88049-970, Florianopolis S.C., Brazil \\ ${ }^{\mathrm{b}}$ Graduate Program in Economics, Federal University of Santa Catarina, 88049-970, Florianopolis S.C., \\ Brazil \\ ${ }^{\mathrm{c}}$ Graduate Program in Economics, Federal University of Espirito Santo, 29075-910, Vitoria E.S., Brazil \\ ${ }^{\mathrm{d} D e p a r t m e n t ~ o f ~ S t a t i s t i c s, ~ U n i v e r s i t y ~ o f ~ B r a s i l i a, ~ 70910-900, ~ B r a s i l i a, ~ D . F ., ~ B r a z i l ~}$ \\ ${ }^{\mathrm{e}}$ Graduate Program in Statistics, University of Brasilia, 70910-900, Brasilia D.F., Brazil \\ ${ }^{\mathrm{f}}$ Graduate Program in Business Administration, University of Brasilia, 70910-900, Brasilia D.F., Brazil
}

Corresponding author: Sergio Da Silva (email: professorsergiodasilva@gmail.com)

\begin{abstract}
The client-bank relationship is based on reciprocity rather than commitment. This situation creates the banker's paradox, as customers who need money the most are at risk for credit and thus unable to obtain a loan. We present survey evidence that a bank marketing strategy that pretends to be a commitment is more successful because clients are evolutionarily adapted to understand the superiority of commitment and be receptive to its cues.
\end{abstract}

\section{Keywords}

Bank marketing; Reciprocity; Commitment.

JEL classification: M37, M31, G21

Financial support

Financial support from CNPq, Capes, and FAP-DF is acknowledged.

\section{Disclosure statement}

The authors declare no competing interests.

Data accessibility

https://doi.org/10.6084/m9.figshare.14540910.v1

https://doi.org/10.6084/m9.figshare.14540943.v1

\section{Introduction}

Cooperation can develop as a result of reciprocity. If I cooperate now, you will be able to cooperate later. Relationships founded on commitment, rather than reciprocity, are a superior form of cooperation (Nesse, 2019). Commitment can explain altruistic acts with no guarantee of future benefits. Banks only operate on the basis of reciprocity. They prefer to lend money on the basis of collateral rather than to those in financial need who lack collateral. This is known as the "banker's paradox" (Tooby and Cosmides, 1996). Customers who require the most money are at risk of credit and are unable to obtain a loan.

We believe that a good marketing strategy is for a bank to imply that there is no banker's paradox and that it will make a loan regardless. In other words, the cooperative relationship between bank and client is founded on reciprocity, but a superior marketing strategy is the bank's suggestion that the relationship is founded on commitment rather than reciprocity. To be more specific, banks do not make loans based solely on collateral. They also provide a variety of unsecured loan products, and secured lending adds an extra layer of security to a loan. Despite this practice, a viable bank should essentially lend money on the basis of collateral, and thus the banker's paradox holds. Perhaps the 
subprime mortgage crisis, which began in 2007, is a good example of the consequences of attempting to overcome the banker's paradox.

The banker's paradox is a theoretical motivation that is alien to economics, in which it is assumed that anyone who requires credit receives it and repays the loan balance. Banks can still profit from borrowers with bad credit because they risk-rate loan interest rates. A loan application must be denied if an applicant is unable to repay it. While this reasoning is sound, if the banker's paradox is at work, customers may react to a marketing strategy that signals commitments rather than reciprocity.

It is not that banks want to attract low-quality borrowers, those who have nothing to offer in return, because a practical corollary of the banker's paradox is that a marketing approach based on it resonates better with all customers indistinctly. As a result, we can ignore demographic data and, in particular, whether a participant is primarily a low or high credit risk in terms of the research design.

When you enter into a relationship based on commitment, you will receive assistance even if you have little to offer in return. However, you must persuade others that you will do something that is not in your best interests in the future. Others must also be convinced that you will assist when there is no way to enforce the obligation. The solution is for you to continue with altruistic actions that show your dedication (Nesse, 2019).

There are compelling reasons to believe that commitment-based cooperation adaptations have evolved (Tooby and Cosmides, 1996). As a result, the bank's marketing strategy is likely to succeed because customers appear to have evolved to understand the superiority of commitment and to be receptive to commitment cues. Our distinction between reciprocity and commitment is potentially more general than the more common distinction in marketing literature between functional and symbolic value, or transactional and relationship value (Brock Smith and Colgate, 2007).

We put this marketing strategy to the test by sending advertising slogans to people based on two types of cooperation: reciprocity and commitment. People seem to prefer slogans in which a bank suggests a commitment-based relationship.

Thus, we contribute an evolutionary psychology approach to the literature, demonstrating that commitment is a critical component of an effective bank marketing strategy. The prior literature identifies the pursuit of commitment as a solid bank marketing strategy, but it does not address the issue of bank advertising head on, as we do here.

In their study of what motivates bank loyalty, Taleghani et al. (2011) look at commitment and reciprocity, which is related to customer preferences. Geyskens et al. (1996) distinguish between two types of commitment: 1) affective commitment, which expresses how much people enjoy maintaining their relationships with specific partners, and 2) calculative commitment, which assesses how much people feel compelled to do so.

Furthermore, trust determines the type of commitment that develops. Retail banks should focus on their customer relationship management strategy components, according to Menon and O'Connor (2007), because this promotes affective commitment to the consumer and maximizes client retention. Affective commitment is generated by "moments of truth" or events of interpersonal customer-bank interaction, according to the authors. This viewpoint is consistent with the social psychology finding that good interpersonal interactions are dependent on the level of assertiveness and attachment demonstrated in the exchange. They go on to say that bankers should target specific clients based on their profitability and longevity, and then deliver appropriate levels of assertiveness and attachment for each. 
Moreover, Strandberg et al. (2015) discovered that affective commitment is more significant to customer loyalty than calculative commitment, emphasizing the necessity of forming emotive bonds with customers. As a result, personal advisers play a crucial role in the banking-customer interaction. Advocacy and collaboration are directly associated to affective commitment, according to Boateng and Narteh (2016), while trust modulates the impact of engagement and personalization on affective commitment. According to Vella et al. (2012), equity sensitivity has a favorable impact on organizational commitment, but perceived bank performance has an impact as well.

In short, there is well-established case-study evidence to support the proposition that commitment is critical in underpinning bank-customer relationships (see also Meyer and Allen, 1991; Anderson and Weitz, 1992; Morgan and Hunt, 1994; Pritchard et al., 1999; Gilliland and Bello, 2002; Fullerton, 2003, 2005, 2011; Adamson et al., 2003; Bansal et al., 2004; Kelly, 2004; Gounaris, 2005; Gustafsson et al., 2005; Palmatier et al., 2006; Bloemer and Odekerken-Schröder, 2007; Ogba, 2008; Davis-Sramek et al., 2009; Cater and Zabkar, 2009; Keh and Xie, 2009; Cater and Cater, 2010; Aurier and N'Goala, 2010; Jones et al., 2010; Beatty et al., 2012; Jain et al., 2014; Ojeme et al., 2016).

\section{Materials and methods}

Bank slogans were created using both a reciprocity and a commitment rule. The slogans are based on evolutionary psychology's current belief that commitment-based cooperation is superior to reciprocity-based cooperation (Nesse, 2019). The relationship between the bank and the client, in particular, is founded on reciprocity. However, this leads to the banker's paradox: the most vulnerable consumers are denied credit. Because a consumer is more likely to think that commitment is superior, the bank gains by selling a tagline that indicates commitment rather than reciprocity, obfuscating the banker's paradox.

As a result, the reciprocity rule we considered was as follows. If I (the bank) cooperate now, you (the customer) will be able to cooperate later. Based on this rule, we came up with the following eight slogans.

1. Quick and easy credit, you will thank us.

2. Security for your money, your trust in our services.

3. Borrow now and pay back later with your loyalty.

4. We value your trust, and you value us with your business.

5. He who gives also receives.

6. A bank that values your time and money is a bank that values your trust.

7. More money-saving ideas and increased trust in your bank.

8. Our expertise applied to your money, earning your trust in return.

The following was the commitment rule we considered. Customers who require the most money are at risk for credit and cannot obtain a loan; nonetheless, the bank should recommend taking out a loan in any event. The following are the eight advertising slogans we came up with based on this criterion.

1. A bank for when you really need it.

2. A bank that is always by your side, both up and down.

3 A bank that is more of a partner than a bank.

4. Created just for you, today and forever.

5. Staying close to you without expecting anything in return.

6. Credit for those times when you really need it.

7. Go to the bank that is always there for you.

8. A bank that understands that there are some things that money cannot buy. 
In order to create the above-mentioned slogans, we first researched current and historical real-world advertising slogans used by banks. The primary source of inspiration for the eight commitment slogans was the hypothesis that banks are already engaged in advertising signaling commitment. Then, whenever it implied that the bank would make a loan in any case, regardless of the banker's paradox, we expanded on an existing slogan. In terms of the eight slogans of reciprocity, we followed the rule that "if the bank cooperates now, the customer can cooperate later."

Cronbach's alphas and Kaiser-Meyer-Olkin (KMO) sampling adequacy measures attest to the validity and reliability of these bank slogans (Table 1).

Table 1. Internal consistency of the sets of bank slogans.

\begin{tabular}{lll}
\hline & Cronbach's alpha & KMO statistic \\
\hline Reciprocity slogans & 0.821 & 0.874 \\
Commitment slogans & 0.671 & 0.767 \\
\hline
\end{tabular}

As a result, we submitted the slogans to two age groups, 18-24 and 40-64, primarily from the Florianopolis area of Brazil, via a Google Forms questionnaire. There were 413 answers. The anonymous participants were asked to assess the sixteen questions above on an emoticon scale. This design is simple and maximizes adhesion. We only asked for participants' ages and said, "We are intending to start a new bank and would appreciate your input on which advertising slogan to utilize."

\section{Results}

To analyze the responses, we assigned the values $0,1,2,3$ to the emoticon scale's increasing satisfaction, as shown in Table 2 . Then we ran a principal component analysis (PCA) across the 16 variables, which were labeled as $c 1-c 8$ for commitment slogan ratings and $r 1-r 8$ for reciprocity slogan ratings. To perform the PCA, we used R's FactoMineR and factoextra packages.

Figure 1 illustrates a scree plot with the cumulative percentage of variance explained by the components and a variables factor map, which shows the 16 variables' principal component scores on the first two dimensions. Table 3 summarizes the results of the first two components. The datasets containing the responses as well as the $\mathrm{R}$ code are available on Figshare.

Our dataset is separated into two subsets by the second component, which completely distinguishes $c 1-c 8$ (negative ratings) from $r 1-r 8$ (positive scores). And, based on the first component, we can see that absolute scores within each group are rather similar (0.53-0.68 and 0.30-0.53). As a result, we conclude that all slogans contribute equally to the overall score. Therefore, the aggregates $C=c 1+\ldots+c 8$ and $R=r 1+\ldots+$ $r 8$ can simply be defined as overall indices.

The empirical densities of the $C$ and $R$ distributions are compared in Figure 2. The commitment bank slogans receive significantly higher overall ratings than the reciprocity slogans. The bootstrapped confidence interval for the 99 percent paired differences $C-R$ is $[2.00 ; 3.17]$, confirming the overall preference for commitment slogans.

Thus, the findings cannot rule out the possibility that a bank marketing approach of communicating commitment in advertising slogans is well received by clients, who can be evolutionarily adapted to realize that commitment is a superior type of cooperation than reciprocity. However, further research should look into whether customers have developed a "commitment skepticism bias" (Buss, 2019) that reduces the costs of being duped by banks. Customers should, after all, be aware of the banker's paradox. 


\section{Discussion}

Marketing theory focuses on two questions: 1) why do people and organizations engage in exchange relationships, and 2) how are exchanges produced, handled, or avoided (Kotler and Levy, 1969; Kotler, 1972; Bagozzi, 1975). These two problems are precisely addressed by our evolutionary psychology approach. The bank and the customer have a reciprocity exchange relationship, but the bank uses slogans to indicate that the exchange is based on commitment rather than reciprocity. As a result, the bank acts as if it had solved the banker's paradox. Furthermore, the bank's stance implies that commitment in buyer-seller relationships is positively associated to trust, a phenomenon widely documented in the literature (Vohra and Bhardwaj, 2019; Ganesan and Hess, 1997).

According to a meta-analysis of 76 independent samples from 56 studies, commitment has a significant impact on brand success (Eisend and Stokburger-Sauer, 2013). As a result, it is not surprising that a bank chooses a slogan strategy that signals commitment rather than reciprocity. Furthermore, because the problem posed by the banker's paradox is pervasive, the use of slogans based on commitment is likely to flourish in other industries. And, thanks to today's computer-generated slogans, success in the banking industry can easily spill over (Alnajjar and Toivonen, 2021; Dowling and Kabanoff, 1996).

The banker's paradox is a metaphor for a broader adaptive problem: when a hunter-gatherer ancestor desperately needs assistance, it becomes a bad "credit risk" and is thus less appealing as a potential recipient of the assistance (Tooby and Cosmides 1996). However, in this case, we take the banker's paradox literally, as well as its marketing strategies. The solution to the banker's paradox is to choose cognitive machinery that is designed to benefit others even in the absence of traditional reciprocation. When people become angry when they hear that friendship is solely based on the reciprocal exchange of favors, this solution comes into play (Tooby and Cosmides, 1996).

This solution is at work in our problem when the bank selects advertising slogans. The bank benefits from the customer's psychological adaptations that may have evolved to accept the bank's slogan suggestions as credible. Despite the "unethical" advertising, the customer perceives the bank strategy as "meaningful marketing," as it increases purchase intentions via the mediating influence of perceived benevolence (Puligadda et al., 2014).

Finally, we point out that our evolutionary approach differs from the more traditional assumption that advertising has a rational impact on consumers. Psychological adaptations, after all, pertain to unconscious inclinations. Consumers, on the other hand, may mentally register basic but powerful advertising associations, which can impact their responses to advertisements intuitively (Heath, 2001).

\section{Conclusion}

Customers who needs the most bank money are at risk of credit and are unable to obtain a loan from the bank. Because the cooperation involved in a bank-client relationship is of the reciprocity type, this banker's paradox arises. A bank marketing strategy that pretends to be a commitment, on the other hand, is more likely to be successful because clients are evolutionarily adapted to understand the superiority of commitment and be receptive to its cues. This hypothesis could not be refuted based on the results of our survey of 413 participants. 
Table 2. Ratings of the bank slogans.

\section{Reciprocity slogans}

1. Quick and easy credit, you will thank us.

2. Security for your money, your trust in our services.

3. Borrow now and pay back later with your loyalty.

4. We value your trust, and you value us with your business.

5. He who gives also receives.

6. A bank that values your time and money is a bank that values your trust.

7. More money-saving ideas and increased trust in your bank.

8. Our expertise applied to your money, earning your trust in return.

\section{Commitment slogans}

1. A bank for when you really need it.

2. A bank that is always by your side, both up and down.

3 A bank that is more of a partner than a bank.

4. Created just for you, today and forever.

5. Staying close to you without expecting anything in return.

6. Credit for those times when you really need it.

7. Go to the bank that is always there for you.

\begin{tabular}{|c|c|c|c|c|c|}
\hline 0 & 1 & 2 & 3 & Mean & Varianc \\
\hline 98 & 178 & 99 & 38 & 1.19 & 0.81 \\
\hline 50 & 123 & 131 & 109 & 1.72 & 0.97 \\
\hline 113 & 187 & 68 & 45 & 1.11 & 0.86 \\
\hline 149 & 171 & 65 & 28 & 0.93 & 0.79 \\
\hline 122 & 189 & 71 & 31 & 1.03 & 0.77 \\
\hline 93 & 161 & 97 & 62 & 1.31 & 0.97 \\
\hline 47 & 115 & 168 & 83 & 1.69 & 0.84 \\
\hline 96 & 153 & 95 & 69 & 1.33 & 1.02 \\
\hline 19 & 102 & 177 & 115 & 1.94 & 0.71 \\
\hline 41 & 118 & 183 & 71 & 1.69 & 0.76 \\
\hline 89 & 131 & 125 & 68 & 1.42 & 1.01 \\
\hline 54 & 89 & 162 & 108 & 1.78 & 0.96 \\
\hline 122 & 129 & 107 & 55 & 1.23 & 1.04 \\
\hline 33 & 143 & 172 & 65 & 1.65 & 0.70 \\
\hline 48 & 125 & 165 & 75 & 1.65 & 0.83 \\
\hline 64 & 138 & 135 & 76 & 1.54 & 0.93 \\
\hline
\end{tabular}
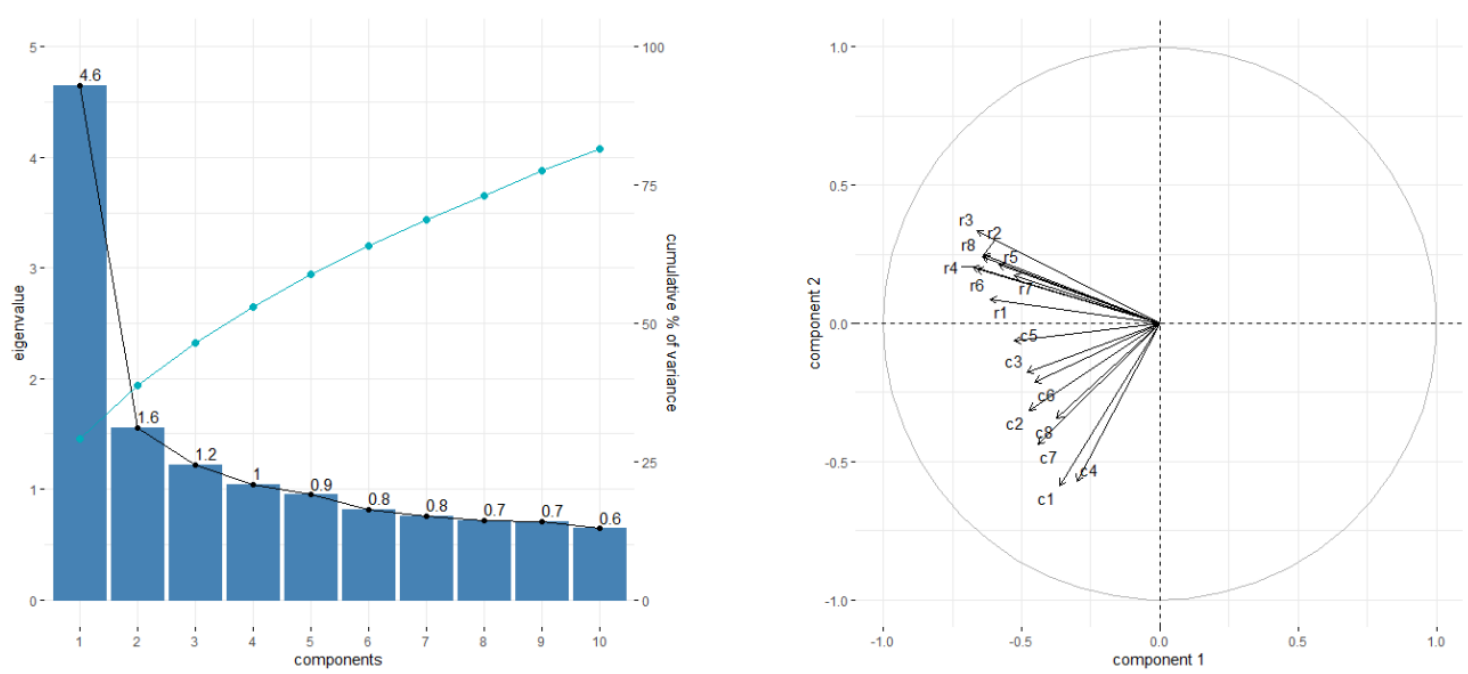

Figure 1. PCA scree plot with cumulative percentage of variance explained (left) and variable factor map (right).

Table 3. PCA coordinates of the first two components.

\begin{tabular}{lll}
\hline Variable & Component 1 & Component 2 \\
\hline$r 1$ & -0.61 & 0.09 \\
$r 2$ & -0.64 & 0.24 \\
$r 3$ & -0.66 & 0.34 \\
$r 4$ & -0.68 & 0,20 \\
$r 5$ & -0.58 & 0.21 \\
$r 6$ & -0.66 & 0.20 \\
$r 7$ & -0.53 & 0.18 \\
$r 8$ & -0.64 & 0.25 \\
$c 1$ & -0.36 & -0.59 \\
$c 2$ & -0.47 & -0.31 \\
$c 3$ & -0.48 & -0.18 \\
$c 4$ & -0.30 & -0.57 \\
$c 5$ & -0.53 & -0.06 \\
$c 6$ & -0.45 & -0.21 \\
$c 7$ & -0.44 & -0.44 \\
$c 8$ & -0.37 & -0.34 \\
\hline
\end{tabular}




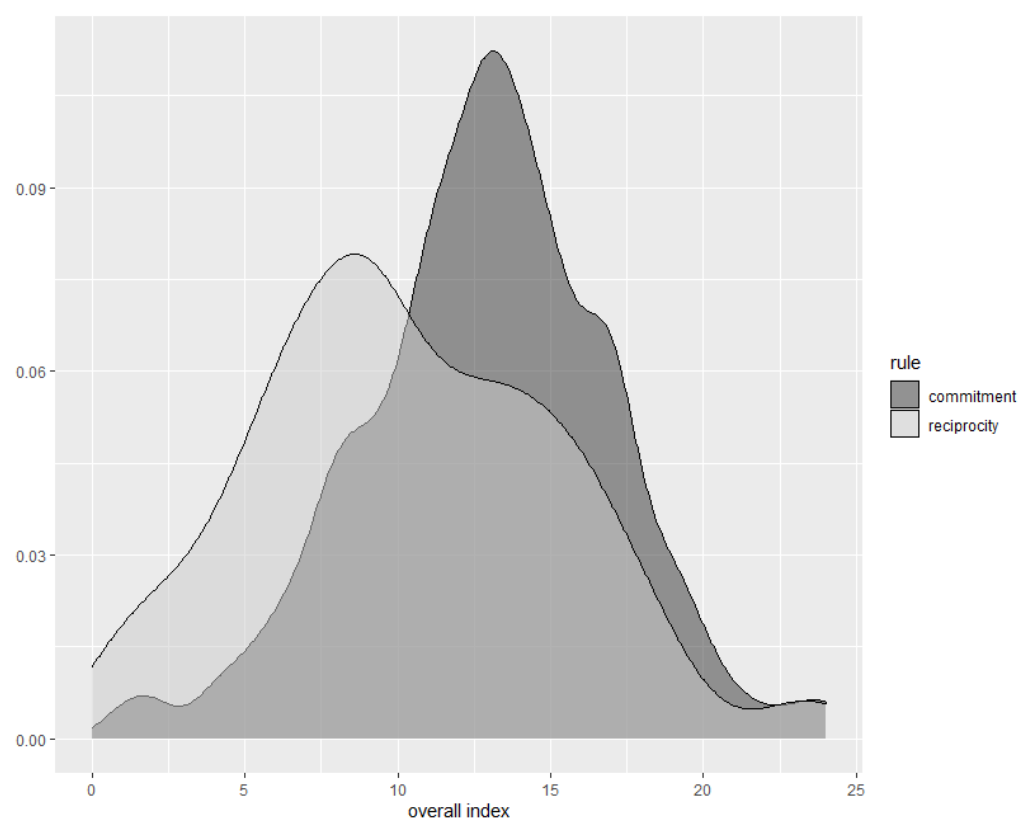

Figure 2. Ratings for commitment bank slogans outperform ratings for reciprocity slogans.

\section{References}

Adamson, I., K.M. Chan, and D. Handford. 2003. "Relationship marketing: Customer commitment and trust as a strategy for the smaller Hong Kong corporate banking sector." International Journal of Bank Marketing 21: 347-358.

https://doi.org/10.1108/02652320310498492

Alnajjar, K., and H. Toivonen. 2021. "Computational generation of slogans.” Natural Language Engineering 27: 575-607.

https://doi.org/10.1017/S1351324920000236

Anderson, E., and B. Weitz. 1992. "The use of pledges to build and sustain commitment in distribution channels." Journal of Marketing Research 29: 18-34.

https://doi.org/10.2307/3172490

Aurier, P., and G. N'Goala. 2010. "The differing and mediating roles of trust and relationship commitment in service relationship maintenance and development." Journal of the Academy of Marketing Science 38: 303-325.

https://doi.org/10.1007/s11747-009-0163-z

Bagozzi, R.P. 1975. "Marketing as exchange.” Journal of Marketing 39: 32-39. https://doi.org/10.2307/1250593

Bansal, H.S., P.G. Irving, and S.F. Taylor. 2004. "A three component model of customer commitment to service providers." Journal of the Academy of Marketing Science 32: 234250.

https://doi.org/10.1177/0092070304263332 
Beatty, E.S., S.M. Reynolds, M.S. Noble, and P.M. Harrison. 2012. "Understanding the relationships between commitment and voice: Hypothesis, empirical evidence and directions for future research." Journal of Service Research 15: 296-315.

https://doi.org/10.1177/1094670512440835

Bloemer, J., and G. Odekerken-Schröder. 2007. "The psychological antecedents of enduring customer relationships: An empirical study in a bank setting." Journal of Relationship Marketing 6: 21-43.

https://doi.org/10.1300/J366v06n01_03

Boateng, S., and B. Narteh. 2016. "Online relationship marketing and affective customer commitment: The mediating role of trust." Journal of Financial Services Marketing 21: 127-140.

https://doi.org/10.1057/fsm.2016.5

Brock Smith, J., and M. Colgate. 2007. "Customer value creation: A practical framework." Journal of Marketing Theory and Practice 15: 7-23.

https://doi.org/10.2753/MTP1069-6679150101

Buss, D.M. (2019) Evolutionary Psychology, 6e. New York: Routledge.

Cater, T., and B. Cater. 2010. "Product and relationship quality influence on customer commitment and loyalty in B2B manufacturing relationships." Industrial Marketing Management 39: 1321-1333.

https://doi.org/10.1016/j.indmarman.2010.02.006

Cater, B., and V. Zabkar. 2009. "Antecedents and consequences of commitment in marketing research services: The client's perspective." Industrial Marketing Management 38: 785-797.

https://doi.org/10.1016/j.indmarman.2007.10.004

Davis-Sramek, B., C. Droge, J.T. Mentzer, and M.B. Myers. 2009. "Creating commitment and loyalty behaviour among retailers: What are the roles of service quality and satisfaction?" Journal of the Academy of Marketing Science 37: 440-454.

https://doi.org/10.1007/s11747-009-0148-y

Dowling, G.R., and B. Kabanoff. 1996. "Computer-aided content analysis: What do 240 advertising slogans have in common?” Marketing Letters 7: 63-75.

https://doi.org/10.1007/BF00557312

Eisend, M., and N.E. Stokburger-Sauer. 2013. "Brand personality: A meta-analytic review of antecedents and consequences." Marketing Letters 24: 205-216. https://doi.org/10.1007/s11002-013-9232-7

Fullerton, G. 2003. "When does commitment lead to loyalty?" Journal of Service Research 5: 333-344. https://doi.org/10.1177/1094670503005004005

Fullerton, G. 2005. "How commitment both enables and undermines marketing relationships.” European Journal of Marketing 39: 137-138. 
Fullerton, G. 2011. "Creating advocates: The roles of satisfaction, trust and commitment." Journal of Retailing and Consumer Services 18: 92-100.

https://doi.org/10.1016/j.jretconser.2010.10.003

Ganesan, S., and R. Hess. 1997. "Dimensions and levels of trust: Implications for commitment to a relationship." Marketing Letters 8: 439-448.

https://doi.org/10.1023/A:1007955514781

Geyskens, I., J.B.E.M. Steenkamp, L.K. Scheer, and N. Kumar. 1996. "The effects of trust and interdependence on relationship commitment: A trans-Atlantic study." International Journal of Research in Marketing 13: 303-317.

https://doi.org/10.1016/S0167-8116(96)00006-7

Gilliland, D.I., and D.C. Bello. 2002. "Two sides to attitudinal commitment: The effect of calculative commitment and loyalty commitment on enforcement mechanisms in distribution channels." Journal of the Academy of Marketing Science 30: 24-43.

https://doi.org/10.1177/03079450094306

Gounaris, S.P. 2005. "Trust and commitment influences on customer retention: Insights from business-to-business services." Journal of Business Research 58: 126-140.

https://doi.org/10.1016/S0148-2963(03)00122-X

Gustafsson, A., M.D. Johnson, and I. Roos. 2005. "The effects of customer satisfaction, relationship commitment dimensions, and triggers on customer retention." Journal of Marketing 61: 210-218.

https://doi.org/10.1509/jmkg.2005.69.4.210

Heath, R. 2001. "Low involvement processing: A new model of brand communication." Journal of Marketing Communications 7: 27-33.

https://doi.org/10.1080/13527260123019

Jain, M., S. Khalil, W.J. Johnston, and J.M.S. Cheng. 2014. "The performance implications of power-trust relationship: The moderating role of commitment in the supplier-retailer relationship.” Industrial Marketing Management 43: 312-321.

https://doi.org/10.1016/j.indmarman.2013.09.001

Jones, T., G.L. Fox, S.F. Taylor, and L.R. Fabrigar. 2010. "Service customer commitment and response." Journal of Services Marketing 24: 16-28.

https://doi.org/10.1108/08876041011017862

Keh, T.H., and Y. Xie. 2009. "Corporate reputation and customer behavioural intentions: The role of trust, identification and commitment." Industrial Marketing Management 38: 732-742.

https://doi.org/10.1016/j.indmarman.2008.02.005

Kelly, S.J. 2004. "Measuring attitudinal commitment in business-to-business channels." Marketing Intelligence and Planning 22: 636-651.

https://doi.org/10.1108/02634500410559024 
Kotler, P. 1972. “A generic concept of marketing." Journal of Marketing 36: 46-54. https://doi.org/10.1177/002224297203600209

Kotler, P., and S.J. Levy. 1969. "Broadening the concept of marketing." Journal of Marketing 33: 10-15.

https://doi.org/10.2307/1248740

Menon, K., and A. O'Connor. 2007. 'Building customers' affective commitment towards retail banks: The role of CRM in each 'moment of truth'." Journal of Financial Services Marketing 12: 157-168.

https://doi.org/10.1057/palgrave.fsm.4760068

Meyer, J.P., and N.J. Allen. 1991. "A three-component conceptualization of organizational commitment." Human Resource Management Review 1: 61-89.

https://doi.org/10.1016/1053-4822(91)90011-Z

Morgan, R.M., and S.D. Hunt. 1994. "The commitment-trust theory of relationship marketing." Journal of Marketing 58: 20-38.

https://doi.org/10.2307/1252308

Nesse, R.M. 2019. Good Reasons for Bad Feelings: Insights from the Frontier of Evolutionary Psychiatry. New York: Dutton.

Ogba, I.E. 2008. "Commitment in the workplace: The impact of income and age on employee commitment in Nigerian banking sector." Management Research News 31: 867-878.

https://doi.org/10.1108/01409170810913051

Ojeme, M., A. Robson, and N. Coates. 2016. "Nigerian SMEs: Commitment and loyalty to their banks." Journal of Financial Services Marketing 21: 325-339. https://doi.org/10.1057/s41264-016-0009-y

Palmatier, R.W., R.P. Dant, D. Grewal, D., and K.R. Evans. 2006. "Factors influencing the effectiveness of relationship marketing: A meta-analysis." Journal of Marketing 70: 136-153.

https://doi.org/10.1509/jmkg.70.4.136

Pritchard, M.P., M.E. Havitz, and D.R. Howard. 1999. "Analyzing the commitmentloyalty link in service contexts." Journal of the Academy of Marketing Science 27: 333348.

https://doi.org/10.1177/0092070399273004

Puligadda, S., D. DelVecchio, and B. Gilbreath. 2014. "Meaningful marketing': A process investigation of how consumers reward noninterruptive, nonpersuasive marketing communication." Journal of Marketing Communications 20: 325-338.

https://doi.org/10.1080/13527266.2012.693121 
Strandberg, C., O. Wahlberg, and P. Ohman. 2015. "Effects of commitment on intentional loyalty at the person-to-person and person-to-firm levels." Journal of Financial Services Marketing 20: 191-207.

https://doi.org/10.1057/fsm.2015.13

Taleghani, M., S. Gilaninia, and S.J. Mousavian (2011). "The role of relationship marketing in customer orientation process in the banking industry with focus on loyalty." International Journal of Business and Social Science 2: 155-166.

https://ijbssnet.com/journals/Vol_2_No_19_Special_Issue_October_2011/18.pdf

Tooby, J., and L. Cosmides. 1996. "Friendship and the banker's paradox: Other pathways to the evolution of adaptations for altruism." Proceedings of the British Academy 88: 119143.

Vella, J., A. Caruana, and L. Pitt. 2012. "Perceived performance, equity sensitivity and organisational commitment among bank managers." Journal of Financial Services Marketing 17: 5-18.

https://doi.org/10.1057/fsm.2012.1

Vohra, A., and N. Bhardwaj. 2019. "From active participation to engagement in online communities: Analysing the mediating role of trust and commitment." Journal of Marketing Communications 25: 89-114.

https://doi.org/10.1080/13527266.2017.1393768 